\title{
A new approach for detoxification of landfill leachate using Trametes trogii
}

\author{
Yosr Smaoui $^{\mathbf{1}^{\dagger}}$, Mariem Fersi ${ }^{2}$, Tahar Mechichi ${ }^{3}$, Sami Sayadi ${ }^{4}$, Jalel Bouzid ${ }^{\mathbf{1}}$ \\ ${ }^{1}$ Laboratory of Environmental Engineering and Eco Technology, National School of Engineers of Sfax, University of Sfax, BP W, 3038, Sfax, Tunisia \\ ${ }^{2}$ Algae Biotechnology Unit, National School of Engineers of Sfax, University of Sfax, BP W, 3038, Sfax, Tunisia \\ ${ }^{3}$ Laboratory of Enzymatic Engineering and Microbiology, National School of Engineers of Sfax, University of Sfax, BP W, 3038, Sfax, Tunisia \\ ${ }^{4}$ Environmental Bioprocesses Laboratory, LMI Cosys-Med, Centre of Biotechnology of Sfax, BP: " 1177 », 3018, Sfax, Tunisia
}

\begin{abstract}
Landfill leachate constitutes one of the most polluting wastewaters. Their treatment was considered difficult due to the presence of high concentration of organic matter, ammonia, toxic organic compounds and heavy metals. Biological processes were found to be effective in several cases, but they are limited by the presence of inhibitory compounds in leachate. In this study we develop a biological process for the leachate biodetoxification using Trametes trogii (T. trogii; CLBE55). Results show that laccase activity, mycelia growth and chemical oxygen demand (COD) removal efficiencies varied depending on the leachate and ammonium concentration. Indeed T. trogii was able to grow in the presence of low concentration of landfill leachate of 10 and 30\%. In fact, the biomass produced was 4.7 and $3.7 \mathrm{~g} / \mathrm{L}$, respectively leading to a COD removal of 66 and $53 \%$, respectively. However, when the concentration of the introduced leachate exceeds $30 \%$, the treatment efficiency and particularly the COD removal decreases to reach $15 \%$ at $100 \%$ leachate. The effect of the ammonia was also studied and results showed that the addition of $5 \mathrm{~g} / \mathrm{L}$ of ammonia inhibited totally the production of laccase and the COD removal.
\end{abstract}

Keywords: Ammonia, Biomass, COD removal, Laccase activity, Landfill leachate, Trametes trogii

\section{Introduction}

Landfill leachate (LFL) is generated as a result of the interaction between rainfall water and solids wastes disposed in landfill sites. Their high rate of organic matter, minerals, heavy metals and xenobiotic contaminants [1] constitute therefore a threat to environment and can exert serious detrimental effects on the surrounding ecosystems [2]. The implementation of an appropriate technique for the treatment of leachate depends on the characteristics of the particular waste stream [3], characteristics and age of the leachate [4]. Indeed, the removal of organic compounds based on chemical oxygen demand (COD), biological oxygen demand (BOD), and ammonium from leachate is the usual prerequisite before discharging it into natural waters [5]. Biological processes are part of the most environmental friendly and economical treatment. They offer many advantages in terms of simplicity and effectiveness [6]. However, they strongly limited by the presence of inhibitory com-

This is an Open Access article distributed under the term of the Creative Commons Attribution Non-Commercial License (http://creativecommons.org/licenses/by-nc/3.0/) which permits unrestricted non-commercial use, distribution, and reproduction in any medium, provided the original work is properly cited.

Copyright (C) 2019 Korean Society of Environmental Engineers pounds in wastewaters [7]. Recently, white rot fungus group has been intensively studied and are gaining increasing importance in the detoxification of wastewaters and removal of a wide range of pollutants [8-10]. The biodegradation capacity of organic pollutants by white rot fungi is correlated with their ability to produce various extracellular enzymes such as lignin peroxidases (LiP), manganese peroxidases $(\mathrm{MnP})$ and laccases. The last ones are able to oxidize nonspecifically various phenolic and non-phenolic compounds using molecular oxygen as the final electron acceptor [11]. Fungal laccases are subjects of increased research in the last decades, because of their wide substrate's range and their wide variety of industrial applications [12], pulp bleaching in the paper industry [13], decolorization of textile dyes [14], biosensors [15], treatment of olive mill wastewater [10] and detoxification of landfill leachate [6]. Specifically, the white-rot fungus Trametes trogii (T. trogii) has received little research attention although it is an outstanding laccase producer and its ability to degrade all lignocellulosic materials [16]. In fact, T. trogii is a

\footnotetext{
${ }^{\dagger}$ Corresponding author

Email: smaoui_yosr@yahoo.fr

Tel: +216-58-532-310 Fax: +216-74-665-190
}

Received January 5, 2018 Accepted July 12, 2018 
worldwide-distributed white-rot basidiomycete that has been recognized as an excellent source of ligninolytic enzymes essentially laccase [17]. Their ability to dye degradation and wastewater detoxification was proved by different authors [18-20]. However, fungal treatment of young landfill leachate has not been well studied to date. The high mineral content is one of the limiting factors for the leachate's biodetoxification by laccases. In fact, the laccase activities decrease sharply when the concentrations of $\mathrm{Cl}^{-}$is higher than $100 \mathrm{mM}$ [21]. In addition, the initial ammonium concentration influences considerably laccase production [22], biomass and enzyme yield [19]. In this context, the objective of this study was to evaluate the potential of $T$. trogii and its extracellular laccase enzyme in the degradation of the organic matter content in the landfill leachate. The effect of the initial concentration of organic matter and ammonia on the efficiency of the treatment was assessed.

\section{Materials and Methods}

The experimental approach adopted in this work is summarized in Fig. 1 and the different analyzes carried out are detailed below.

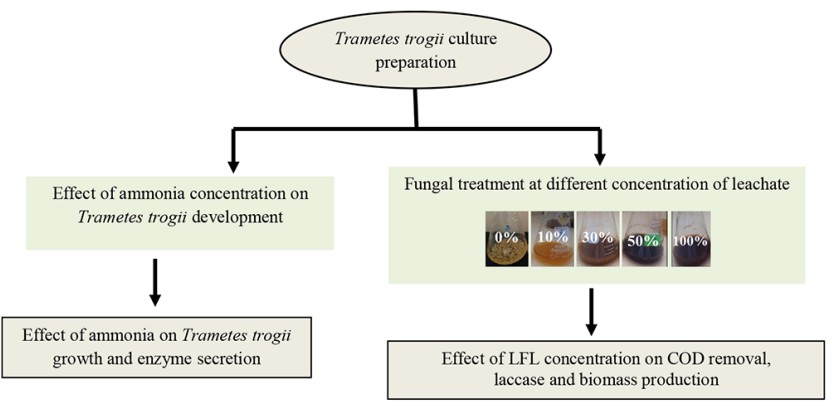

Fig. 1. Experimental approach adopted in this work.

\subsection{Landfill Leachate Sampling}

Landfill leachate was sampled from the controlled discharge of the Sfax region (Tunisia). It was taken straight from the collection box, frozen at $-20^{\circ} \mathrm{C}$ before being used. Table 1 present the physico-chemical characteristics of the LFL.

\subsection{Analytical Methods}

The $\mathrm{pH}$ and electrical conductivity (EC) were measured using a pH-meter (Hanna instrument) and a conductivity-meter (Consort C 831) respectively. The COD was determined using the method described by Knechtel (knechtel, 1978), and the biochemical oxygen demand $\left(\mathrm{BOD}_{5}\right)$ was estimated by means of a respirometer (BSB-Controlled Model Oxitop (WTW)).The total nitrogen content and $\mathrm{N}-\mathrm{NH}^{4+}$ were analyzed by the Kjeldahl-N method. Total phenol concentrations were quantified by the colorimetric method [23]. Volatile fatty acids (VFA) were determined by a gas chromatograph (SHIMADZU) equipped with a flame ionization detector. The total concentrations of $\mathrm{Fe}, \mathrm{Mn}, \mathrm{Zn}, \mathrm{Ni}, \mathrm{Cr}$ and heavy metals were determined using atomic absorption flame emission spectrophotometer with a polarized Zeeman Z-6100 model (Hitachi, Japan).

\subsection{Fungal Strain and Culture Conditions}

The white-rot basidiomycete $T$. trogii (CLBE55) was isolated from decayed acacia wood from North West of Tunisia and selected for its potential of laccase production. For short term preservation, the fungus was grown on malt extract agar at $30^{\circ} \mathrm{C}$ for 5 to 7 $\mathrm{d}$ and then Petri dishes were stored at $4^{\circ} \mathrm{C}$. For laccase production, T. trogii was cultured on M7 medium containing (g/L): glucose, 10; peptone, 5; yeast extract, 1; ammonium tartrate, 2; $\mathrm{KH}_{2} \mathrm{PO}_{4}$, 1; $\mathrm{MgSO}_{4} \cdot 7 \mathrm{H}_{2} \mathrm{O}, 0.5 ; \mathrm{KCl}, 0.5$; trace elements solution, $1 \mathrm{~mL}$. The $\mathrm{pH}$ of the solution was adjusted to 5.5 prior to autoclaving. Production of laccase was stimulated by adding $300 \mu \mathrm{M}$ of $\mathrm{CuSO}_{4}$ to the culture after $3 \mathrm{~d}$ incubation [24]. The inoculated flasks were continuously shaken on a rotary shaking incubator operating at continuous stirring of $150 \mathrm{rpm}$ and at constant temperature of $30^{\circ} \mathrm{C}$ for $15 \mathrm{~d}$. Different volumes of landfill leachate were added to the Culture in order to reach the already fixed concentration.

\subsection{Laccase Assay}

Laccase activity was assayed using $10 \mathrm{mmol} / \mathrm{L} \mathrm{DMP}$ in $100 \mathrm{mmol} / \mathrm{L}$ sodium acetate buffer, $\mathrm{pH} 5\left(\varepsilon_{469 \mathrm{~nm}}=27,500 \mathrm{M}^{-1} \mathrm{~cm}^{-1}\right)$. Enzymatic reactions were carried out at room temperature $\left(22-25^{\circ} \mathrm{C}\right)$. One unit of enzyme activity was defined as the amount of enzyme oxidizing $1 \mu \mathrm{mol}$ of substrate perminute in $100 \mathrm{mmol} / \mathrm{L}$ sodium acetate buffer, $\mathrm{pH} 5$.

\subsection{Growth Measurements}

Growth was measured in terms of dry weight of washed mycelium after filtration and drying overnight at $105^{\circ} \mathrm{C}$ on glass-fiber filters (GF/D Whatman Inc.). Yields were expressed as grams of dry weight mycelia per liter of culture.

\subsection{Phytotoxicity Tests}

Phytotoxicity was estimated by the determination of the germination index (GI) according to Zucconi et al. [25] using Lepidium sativum seeds. A sample with distilled water was used as a control.

\subsection{Microtoxicity Tests}

Microtoxicity tests were performed by measuring the inhibition rate of bioluminescence of the bacterium Vibrio fischeri ( $V$. fischeri), strain DSMZ 2167. A LUMIStox equipment (GmbH, Dusseldorf, Germany), in accordance with the ISO/DIS 11348-2 (1998) standard, was used for this measurement.

\subsection{Ammonia Solution Addition}

The $\mathrm{NH}_{4} \mathrm{Cl}$ was added at $0.5,1.5,3$ and $5 \mathrm{~g} / \mathrm{L}$ from a sterilized stock solution prepared at $200 \mathrm{~g} / \mathrm{L}$. The control corresponded only to the amount of nitrogen required in the basal medium $(2 \mathrm{~g} / \mathrm{L})$ of ammonium tartrate for $T$. trogii.

\section{Results and Discussion}

\subsection{Characterization of the Landfill Leachate}

Physico-chemical characteristics of the leachate samples collected during the research period are summarized in Table 1. 
Table 1. Physico-chemical Characteristics of Leachate and Legal Limits for Discharge into Urbanized Streams

\begin{tabular}{|c|c|c|}
\hline Parameter & Values & $\mathbf{L L D}^{\mathbf{a}}$ \\
\hline $\mathrm{pH}$ & $8-8.2$ & $6.5-9$ \\
\hline Turbidity (NTU) & 365 & $\mathrm{nd}^{\mathrm{b}}$ \\
\hline $\mathrm{CE}(\mathrm{ms} / \mathrm{cm})$ & $30-40$ & \\
\hline Salts (g/L) & 29 & \\
\hline $\mathrm{TS}(\mathrm{g} / \mathrm{L})$ & $45-46$ & $n d^{b}$ \\
\hline COD ( $\left(\mathrm{g} \mathrm{O}_{2} / \mathrm{L}\right)$ & $35-45$ & 1 \\
\hline $\mathrm{BOD}_{5}\left(\mathrm{~g} \mathrm{O}_{2} / \mathrm{L}\right)$ & $10-13$ & 0.4 \\
\hline $\mathrm{BOD}_{5} / \mathrm{COD}$ & 0.28 & $n d^{b}$ \\
\hline NTK (g/L) & $3-3.5$ & 0.1 \\
\hline $\mathrm{NH}_{4}^{+}(\mathrm{g} / \mathrm{L})$ & $2.7-2.8$ & $\mathrm{nd}^{\mathrm{b}}$ \\
\hline Phenols (g/L) & $0.1-0.3$ & 0.001 \\
\hline Aceticacid (M) & 0.245 & \\
\hline Butyricacid (M) & 0.013 & \\
\hline Isobutyricacid (M) & 0.02 & \\
\hline Propionicacid (M) & 0.136 & \\
\hline $\mathrm{Pb}(\mathrm{mg} / \mathrm{L})$ & $<0.005$ & 1 \\
\hline Cd (mg/L) & $<0.005$ & 0.1 \\
\hline $\mathrm{Fe}(\mathrm{mg} / \mathrm{L})$ & 10-13 & 5 \\
\hline Cr (mg/L) & $0.9-1$ & 1 \\
\hline Ni (mg/L) & $0.05-0.07$ & 2 \\
\hline IG (\%) & 0 & \\
\hline IB (\%) & 100 & \\
\hline
\end{tabular}

$\mathrm{LLD}^{\mathrm{a}}$ : legal limits for discharge into urbanized streams (NT. 106.002); $\mathrm{nd}^{\mathrm{b}}$ : not determined

Leachate used were of dark color due to the presence of humic substances as the most abundant organic components in the leachate [26]. The $\mathrm{pH}$ was in alkaline range and the electric conductivity exceeded $30 \mathrm{~ms} / \mathrm{cm}$ showing a high salt level. The $\mathrm{BOD}_{5} / \mathrm{COD}$ ratio indicated the leachate low biodegradability with a high organic load expressed in COD (40 g/L), and low BOD 5 (12 g/L). The turbidity and the high content of suspended matter were consistent with an important load of colloidal particles present in the effluent. The leachate was also characterized by a high nitrogen level (more than $3 \mathrm{~g} / \mathrm{L}$ ) which could limit bacterial activity and biodegradability [27]. Some mineral micro-pollutants were also detected in LFL. Phenolic compounds were present and exceeded largely the limit concentrations according to Tunisian standards for wastewater release. A high concentration of volatiles fatty acids (VFA) was measured with a predominance of acetic acid $(245 \mathrm{mM})$ and propionic acid (136 $\mathrm{mM}$ ). The raw leachate was very toxic for $V$. fischeri, leading to $100 \%$ of inhibition of bioluminescence. The toxicity of leachate was also demonstrated by seed germination test conducted with different concentrations. Germination was completely inhibited (IG (\%) = 0 ), where the raw leachate or 1/10 diluted solution were applied. According to Zucconi et al. [25], the toxicity of raw wastewater can be overcome when it is used beyond a dilution of 50 times.

As a consequence, treatment of landfill leachate is a priority before discharge into the receiving environment. Fungal treatment using T. trogii was studied for the degradation of organic compounds and some pollutants causing environmental problems.

\subsection{Fungal and Enzymatic Treatment}

\subsubsection{Effect of LFL concentration on COD removal, laccase and biomass production}

Laccase production from T. trogii in M7 medium without any effluent (Fig. 2) showed that after eight days of monitoring, activity peaked with a value of 7,000 U/L, and then decreased gradually.

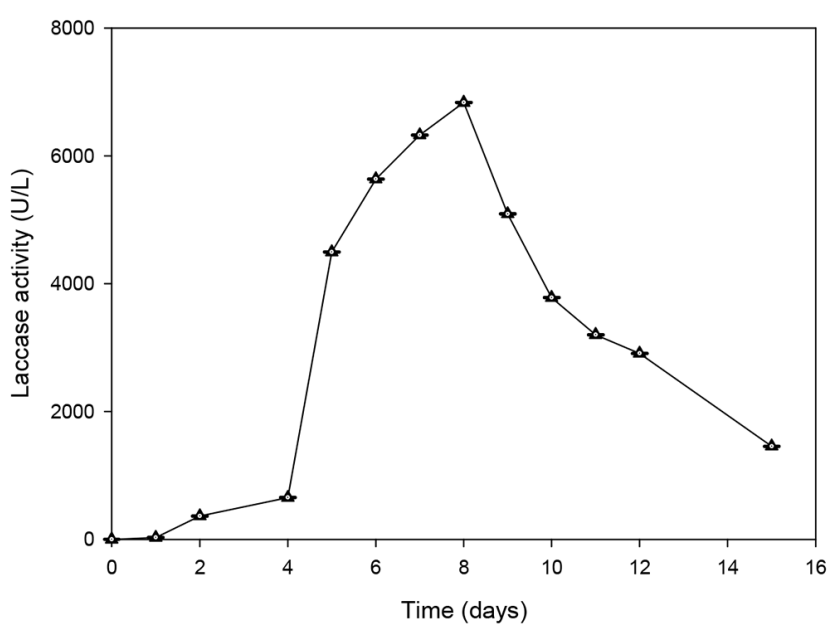

Fig. 2. Laccase production by $T$. trogii strain CLBE55 in M7 medium. (Error bars represent \pm one standard deviation from the mean, $\mathrm{n}=3$ )

The treatment of leachate was carried out at different initial concentration of COD $(40,20,12,4 \mathrm{~g} / \mathrm{L})$ corresponding respectively to different dilutions $(100 \%, 50 \%, 30 \%$ and $10 \%)$ to illustrate the effect of leachate dose on laccase production. A gradual decrease of laccase activity was noticed when the effluent concentration increased (Fig. 3 ). Indeed, a reduction of $65 \%$ was observed by adding only $10 \%$ of leachate and the maximum production was reached 2,200 U/L. The amount of laccase activity did not exceed $140 \mathrm{U} / \mathrm{L}$ and 300 $\mathrm{U} / \mathrm{L}$ for raw and 50\% leachate dilution, respectively. These results suggest that the laccase production inhibition in higher concentration of leachate can be attributed to the presence of high concentration of organic matter and ammonia. These data are consistent with the those of Kalčíková et al. [6] who reported a total inhibition of laccase production using 50\% leachate from active landfill.

The removal of organic matter was correlated with the laccase production (Fig. 4). Indeed, an importantdecrease was observed for cultures containing 10 and 30\% leachate and the COD removal reached 56.6 and $47.36 \%$, respectively at the fourth day of treatment. After $9 \mathrm{~d}$, the removal efficiencies reached the maximum of 66 and 57\%, respectively. According to other previous studies [17, 28, 29], T. trogii is characterized by its degrading ability of problematic compounds presents in wastewater. Ellouze et al. [30] showed that the enzymatic system of $T$. trogii was involved in the degradation of organic compound and the detoxification of leachate was a consequence of the important reduction of phenols, ammonia and hydrocarbons. Similarly, [31] showed that TOC and ammonia reduction with COD increasing in the solution is related to the capacity of extracellular enzymes production. At the end of treatment, the removal of COD decreased and reached 31 and $15 \%$ for 50 and $100 \%$ leachate, respectively. 


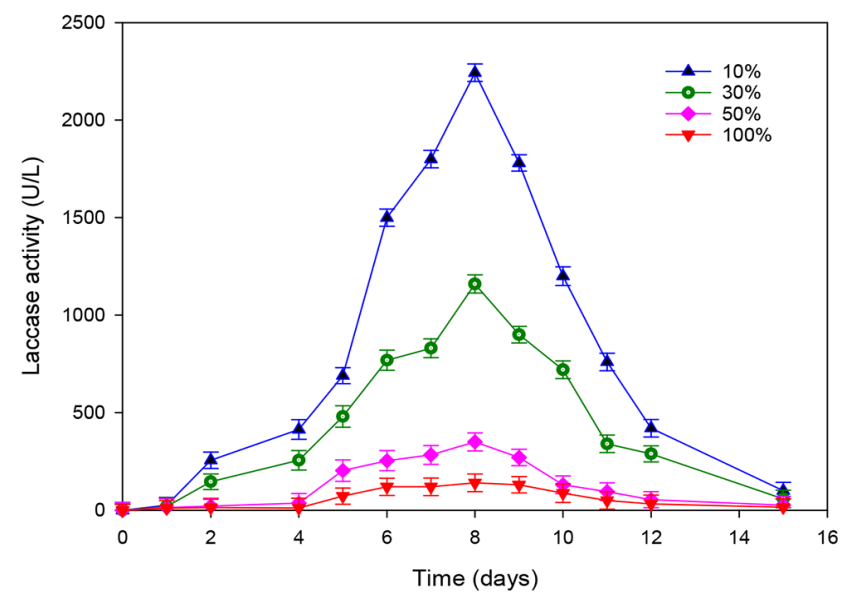

Fig. 3. Effect of leachate concentration on the laccase production by T. trogii. (Error bars represent \pm one standard deviation from the mean, $\mathrm{n}=3$ )

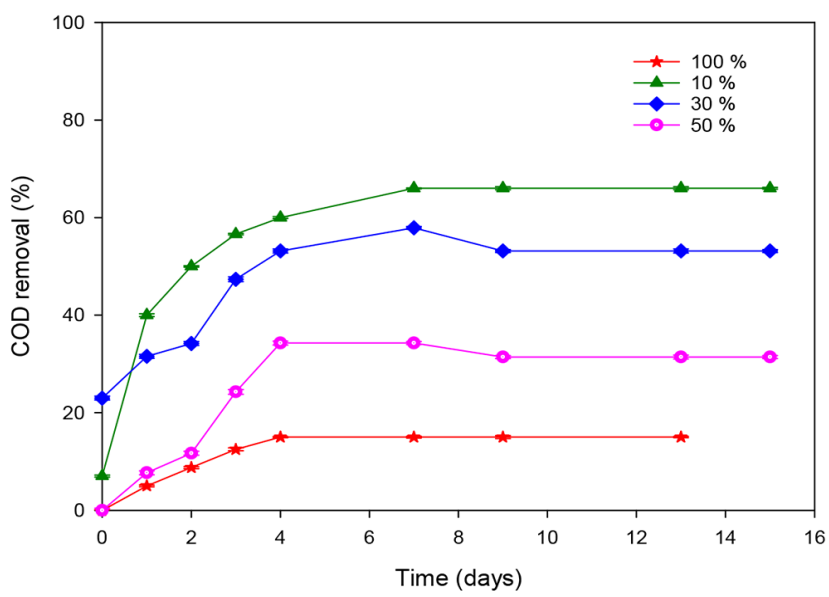

Fig. 4. Monitoring of COD removal during landfill leachate treatment by $T$. trogii. (Error bars represent \pm one standard deviation from the mean, $\mathrm{n}=3$ )

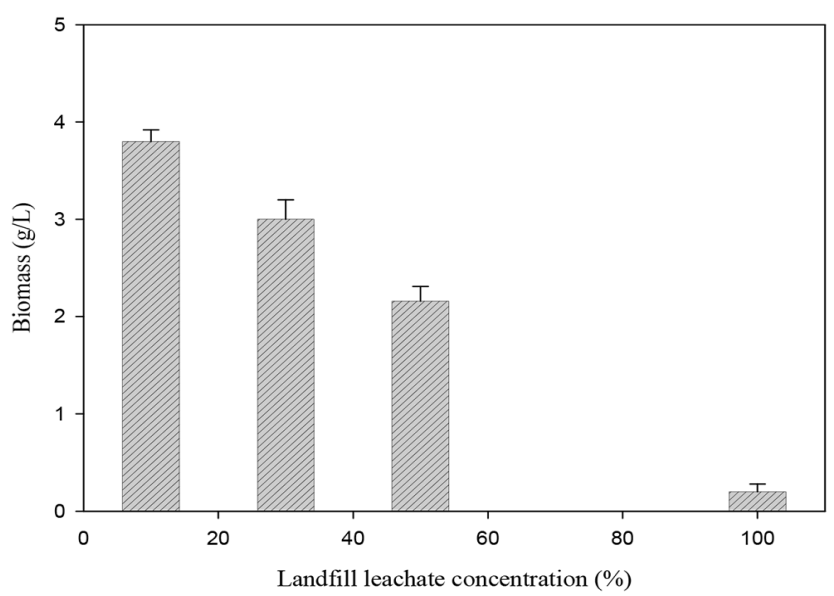

Fig. 5. Effect of LFL concentration on the growth of T. trogii. (Error bars represent \pm one standard deviation from the mean, $\mathrm{n}=3$ )
The investigation of the effect of leachate concentration on T. trogii growth (Fig. 5) showed that biomass production was significantly inhibited with the increase of leachate concentration. Indeed, biomass production was of $3.8 \mathrm{~g} / \mathrm{L}$ with $10 \%$ leachate and it decreased to $3,2.16$ and $0.12 \mathrm{~g} / \mathrm{L}$ with 30,50 and $100 \%$ leachate, respectively.

3.2.2. Effect of ammonia on T. trogii growth and enzyme secretion At adequate level, Nitrogen is an essential nutrient for protein synthesis and enzyme production by fungal organisms. The high amount of ammonia in landfill leachate could be toxic for microorganisms. In fact, it inhibits the bioactivity of microorganisms [32]. To confirm the effect of ammonia concentration on $T$. trogii growth and on its laccase production, different concentrations@ of $\mathrm{NH}_{4} \mathrm{Cl}(0.5,1.5,3$ and 5 g/L) were added to the initial solution contained M7 media. The laccase activity was then determined for each concentration (Fig. 6).

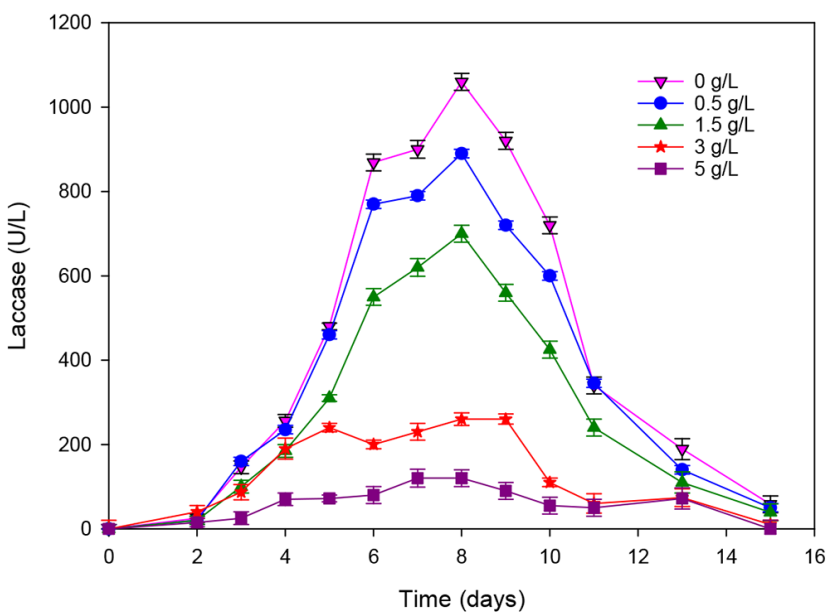

Fig. 6. Effect of the ammonia addition on laccase production. (Error bars represent \pm one standard deviation from the mean, $\mathrm{n}=3$ )

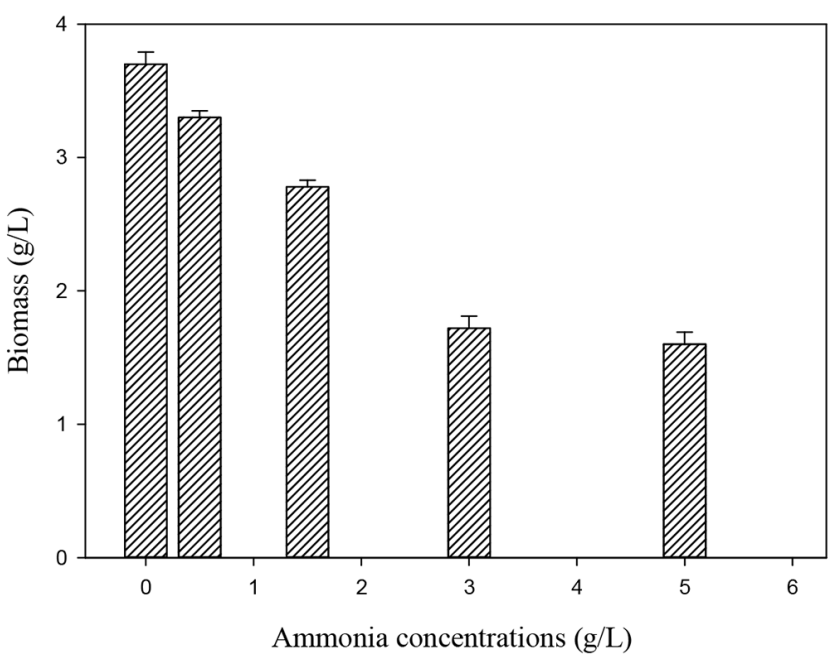

Fig. 7. Effect of ammonia concentration on the growth of $T$. trogii. (Error bars represent \pm one standard deviation from the mean, $\mathrm{n}=3$ ) 
Compared to the control, the addition of $0.5 \mathrm{~g} / \mathrm{L}$ of $\mathrm{NH}_{4} \mathrm{Cl}$ causes an inhibition rate of 16 and $11 \%$ for laccase and biomass production, respectively (Fig. 7). This result agreed with the behavior of many white-rot fungi whose degradative enzymes require nitrogen limitation. However, this result is not in agreement with that of Ellouze et al. [19] who showed that until $1 \mathrm{~g} / \mathrm{L}$ of $\mathrm{NH}_{4} \mathrm{Cl}$, laccase activity was not inhibited, but beyond this concentration the metabolic pathways and the enzyme production were negatively affected because of the nitrogen catabolic repression on the microbial secondary metabolism.

This inhibition increase gradually with the addition of ammonia, it achieved $88 \%$ with the addition of $5 \mathrm{~g} / \mathrm{L}$ of ammonia. At this concentration, the biomass decreased 3 folds (3.7 for the control and only 1.6 for $5 \mathrm{~g} / \mathrm{L}$ ammonia added to the culture). We can conclude that the leachate biodegradability and toxicity constitute a limit for the fungal treatment. In fact, laccase activity is directly affected by organic matter and ammonia contents.

\section{Conclusions}

Landfill leachate showed a high level of organic matter, ammonia and salts. These compounds exert a toxic effect, since they completely inhibited the bioluminescence of $V$. fischeri and the germination of Lepidium sativum seeds. Fungal treatment of leachate using T. trogii was investigated. A high removal of organic matter was observed when treated a low concentration of leachate (10 and $30 \%$ ). The efficiencies decrease gradually with the increase of the leachate concentration. The high ammonia level content can be a reason for these results. In fact, the addition of $5 \mathrm{~g} / \mathrm{L}$ inhibited totally the treatment, with the decrease of the laccase production and then removal of organic matter. In addition, the requirement of high amount of nutrients can constitute a disadvantage of the application of fungal in landfill leachate treatment. Also, the dilution necessary for biological treatment accentuates the leachate volume problem. So, it would be better to optimize the culture conditions for this effluent in order to achieve an efficient detoxification.

\section{References}

1. Amor C, Torres-Socías ED, Peres JA, et al. Mature landfill leachate treatment by coagulation/flocculation combined with Fenton and solar photo-Fenton processes. J. Hazard. Mater. 2015;286:261-268.

2. Contrera RC, da Cruz Silva KC, Morita DM, Rodrigues AD, Zaiat M, Schalch V. First-order kinetics of landfill leachate treatment in a pilot-scale anaerobic sequence batch biofilm reactor. J. Environ. Manage. 2014;145:385-393.

3. Ntampou X, Zouboulis AI, Samaras P. Appropriate combination of physico-chemical methods (coagulation/flocculation and ozonation) for the efficient treatment of landfill leachates. Chemosphere 2006;62:722-730.

4. Ozturk I, Altinbas M, Koyuncu I, Arikan O, Gomec-Yangin C. Advanced physico-chemical treatment experiences on young municipal landfill leachates. Waste Manage. 2003;23:441-446.

5. Raghab SM, Abd El Meguid AM, Hegazi HA. Treatment of leachate from municipal solid waste landfill. HBRC J. 2013;9:187-192.

6. Kalčíková G, Babič J, Pavko A, Gotvajn AZ. Fungal and enzymatic treatment of mature municipal landfill leachate. Waste Manage. 2014;34:798-803.

7. Renou S, Givaudan JG, Poulain S, Dirassouyan F, Moulin P. Landfill leachate treatment: Review and opportunity. J. Hazard. Mater. 2008;150:468-493.

8. Abadulla E, Tzanov T, Costa S, Robra KH, Cavaco-Paulo A, Gubitz M. Decolorization and detoxification of textile dyes with a laccase from Trametes hirsuta. Appl. Environ. Microbiol. 2000;66:3357-3362.

9. Ben Younes S, Cherif I, Dhouib A, Sayadi S. Trametes trogii: A biologic powerful tool for dyes decolorization and detoxification. Catal. Lett. 2016;146:204-211.

10. Nogueira V, Lopes I, Freitas AC, et al. Biological treatment with fungi of olive mill wastewater pre-treated by photocatalytic oxidation with nanomaterials. Ecotoxicol. Environ. Saf. 2015;115:234-242.

11. Polak J, Jarosz-Wilkolazka A. Fungal laccases as green catalysts for dye synthesis. Process Biochem. 2012;47:1295-1307.

12. Kunamneni A, Plou FJ, Ballesteros A, Alcalde M. Laccases and their applications: A patent review. Recent Pat. Biotechnol. 2008;2:10-24.

13. Moldes D, Cadena EM, Vidal T. Biobleaching of eucalypt kraft pulp with a two laccase-mediator stages sequence. Bioresour. Technol. 2010;101:6924-6929.

14. Daâssi D, Rodríguez-Couto S, Nasri M, Mechichi T. Biodegradation of textile dyes by immobilized laccase from Coriolopsis gallica into Ca-alginate beads. Int. Biodeterior. Biodegradation 2014;90:71-78.

15. Ardhaoui M, Bhatt S, Zheng M, Dowling D, Jolivalt C, Khonsari FA. Biosensor based on laccase immobilized on plasma polymerized allylamine/carbon electrode. Mater. Sci. Eng. C. 2013;33:3197-3205.

16. Levin L, Herrmann C, Papinutti VL. Optimization of lignocellulolytic enzyme production by the white-rot fungus Trametes trogii in solid-state fermentation using response surface methodology. Biochem. Eng. J. 2008;39:207-214.

17. Campos PA, Levin LN, Wirth SA. Heterologous production, characterization and dye decolorization ability of a novel thermostable laccase isoenzyme from Trametes trogii BAFC 463. Process Biochem. 2016;51:895-903.

18. Yan J, Chen D, Yang E, Niu J, Chen Y, Chagan I. Purification and characterization of a thermotolerant laccase isoform in Trametes trogii strain and its potential in dye decolorization. Int. Biodeterior. Biodegradation 2014;93:186-194.

19. Ellouze M, Aloui F, Sayadi S. Effect of high ammonia concentrations on fungal treatment of Tunisian landfill leachates. Desalination 2009;246:468-477.

20. Khlifi R, Belbahri L, Woodward S, et al. Decolourization and detoxification of textile industry wastewater by the laccase-mediator system. J. Hazard. Mater. 2010;175:802-808.

21. Jimenez-Juarez N, Roman-Miranda R, Baeza A, Sanchez-Amat A, Vazquez-Duhalt R, Valderrama B. Alkali and halide-resistant 
catalysis by the multipotent oxidase from Marinomonas mediterranea. J. Biotechnol. 2005;117:73-82.

22. Swamy J, Ramsay JA. The evaluation of white rot fungi in the decoloration of textile dyes. Enzyme Microb. Technol. 1999;24:130-137.

23. Box JD. Investigation of the Folin-Ciocalteau phenol reagent for the determination of polyphenolic substances in natural waters. Water Res. 1983;17:511-525.

24. Zouari-Mechichi H, Mechichi T, Dhouib A, Sayadi S, Martinez AT, Martinez MJ. Laccase purification and characterization from Trametes trogii isolated in Tunisia: Decolorization of textile dyes by the purified enzyme. Enzyme Microb. Technol. 2006;39:141-148.

25. Zucconi F, Pera A, Forte M, De Bertoldi M. Evaluating toxicity of immature compost. BioCycle 1981;22:54-57.

26. Seungkwan Hong ME. Chemical and physical aspects of natural organic matter (NOM) fouling of nanofiltration membranes. J. Membr. Sci. 1997;132:159-181.

27. Kjeldsen P, Barlaz MA, Rooker AP, Baun A, Ledin A, Christensen TH. Present and long-term composition of MSW landfill leachate: A review. Crit. Rev. Environ. Sci. Technol. 2002;32:297-336.

28. Badia-Fabregat M, Lucas D, Tuomivirta T, et al. Study of the effect of the bacterial and fungal communities present in real wastewater effluents on the performance of fungal treatments. Sci. Total Environ. 2017;579:366-377.

29. Dammak I, Khoufi S, Sayadi S. A performance comparison of olive oil mill wastewater enzymatic treatments. Food Bioprod. Process. 2016;100:61-71.

30. Ellouze M, Aloui F, Sayadi S. Detoxification of Tunisian landfill leachates by selected fungi. J. Hazard. Mater. 2008;150:642-648.

31. Hu L, Zeng G, Chen G, et al. Treatment of landfill leachate using immobilized Phanerochaete chrysosporium loaded with nitrogen-doped $\mathrm{TiO}_{2}$ nanoparticles. J. Hazard. Mater. 2016;301: 106-118.

32. Liu Z, Dang Y, Li C, Sun D. Inhibitory effect of high $\mathrm{NH}_{4}{ }^{+}-\mathrm{N}$ concentration on anaerobic biotreatment of fresh leachate from a municipal solid waste incineration plant. Waste Manage. 2015;43:188-195. 